The Journal of Animal \& Plant Sciences, 31(2): 2021, Page: 529-541

ISSN (print): 1018-7081; ISSN (online): 2309-8694

\title{
LINE BY TESTER COMBINING ABILITY ANALYSIS FOR EARLINESS AND YIELD TRAITS IN BREAD WHEAT (TRITICUM AESTIVUM L.)
}

\author{
K. Din ${ }^{1}$, N. U. Khan ${ }^{1, *}$, S. Gul' , S. U. Khan ${ }^{3}$, I. H. Khalil ${ }^{1}$, S. A. Khan ${ }^{4}$, S. $\mathrm{Ali}^{4}$, N. Ali ${ }^{4}$, \\ Z. Bibi ${ }^{5}$, K. Afridi ${ }^{1}$, M. Ishaq ${ }^{1}$, and I. A. Khalil ${ }^{1}$ \\ ${ }^{1}$ Department of Plant Breeding and Genetics, The University of Agriculture, Peshawar, Pakistan \\ ${ }^{2}$ Department of Plant Breeding and Genetics, Lasbela University of Agriculture, Water and Marine Sciences \\ (LUAWMS), Uthal, Balochistan, Pakistan \\ ${ }^{3}$ Institute of Biotechnology and Genetic Engineering, The University of Agriculture, Peshawar, Pakistan \\ ${ }^{4}$ Department of Plant Breeding and Genetics, The University of Haripur, Haripur, Pakistan \\ ${ }^{5}$ Department of Soil Science, Faculty of Agriculture, Gomal University, Dera Ismail Khan, Pakistan \\ *Corresponding Author e-mail: nukmarwat@yahoo.com,nukmarwat@aup.edu.pk
}

\begin{abstract}
In the current breeding program, the development of new wheat genotypes with greater genetic potential has become an enduring target to assist in food security. Wheat breeders are also trying to develop such genotypes that can fetch maximum return with limiting resources. Line-by-tester combining ability analysis was carried out during 2015-2018 to determine the genetic divergence, general and specific combining ability (GCA and SCA) among lines, testers, and line by tester interactions, and legacy of agronomic traits in wheat. Six wheat lines i.e., IBWSN-177, IBWSN-52, IBWSN131, SRN-09111, PR-107, and NR-21, and three testers i.e., Pirsabak-15, Shahkar-13, and Pakhtunkhwa-15 were crossed in a line by tester mating fashion. After advancing the generation, eighteen $F_{2}$ populations and nine parental genotypes were grown in a randomized complete block design with three replications and assessed through line by tester combining ability. Analysis of variance revealed significant $(\mathrm{p} \leq 0.01)$ variations among genotypes (parental cultivars and $\mathrm{F}_{2}$ populations) for the studied traits. According to combining ability analysis, lines revealed significant ( $\mathrm{p} \leq 0.01)$ variances for days to heading and harvest index, while merely significant $(\mathrm{p} \leq 0.05)$ for plant height and flag leaf area. However, line by tester interactions revealed significant $(\mathrm{p} \leq 0.01)$ differences for all the variables. Parental genotypes IBWSN-131, Shahkar-13, and $F_{2}$ populations IBWSN-131 $\times$ Pakhtunkhwa-15, IBWSN-131 $\times$ Shahkar-13, and PR107 $\times$ Shahkar-13 were identified as promising general and specific combiners which performed better for earliness and yield traits. High by high, high by low and low by high general combiners were involved in $\mathrm{F}_{2}$ populations with promising SCA and best mean performance. In comparative involvement to the total variance, the lines and $\mathrm{L} \times \mathrm{T} \mathrm{F}_{2}$ populations had a maximum share for the majority of the traits. Ratios of GCA to SCA variances and degree of dominance revealed that all the traits were managed by dominant gene action. Non-additive gene action suggested that selection of promising populations should be postponed to later segregating generations for further improvement.
\end{abstract}

Key words: Additive and dominant gene effects; agronomic traits; the degree of dominance; $\mathrm{F}_{2}$ populations; genetic variability; GCA and SCA variances; Triticum aestivum L.

https://doi.org/10.36899/JAPS.2021.2.0242

Published online October 03,2020

\section{INTRODUCTION}

According to the current census figures, the current estimated population is 221.27 million people in Pakistan (Worldometer, 2020). Looking back to 1955, Pakistan had a population of 40.0 million people only. On the other hand, the use of agricultural land for urbanization is also increasing. To keep the equilibrium between food and population (rising at $2.07 \%$ per year), it is essential to further enhance the wheat production (Afridi et al., 2019). Therefore, it's a great challenge for plant breeders to develop the wheat genotypes with greater genetic potential and to face the water limitations and drought due to changed climatic conditions. Wheat (Triticum aestivum L.) being a major staple food crop represents vital sources of carbohydrate and protein (Sabit et al., 2017; Hama-Amin and Towfiq, 2019). It was first cultivated as a food crop in the Fertile Crescent of the Middle East and has become the primary staple food crop in the majority regions of the world, and to entertain a foremost position in Pakistan agriculture (Ashraf et al., 2015; Afridi et al., 2018). It is nutritionally important cereal, essential for food security, poverty mitigation, and livelihood (Bhanu et al., 2018; Khokhar et al., 2019). Significant research work has been carried out on increasing the wheat productivity and still need more which is the response to the pressure of ample food supply to regularly increasing population in Pakistan and the world as a whole (Afridi et al., 2017a; Ahmad et al., 2017; Parveen et al., 2019). 
For improvement in wheat yield, the study of genetic composition, the tendency of combining ability and plant behavior is of great importance for wheat breeders (Griffing, 1956; Kempthorne, 1957). Combining ability analysis is one of the prevailing tools to compare the performance of parental genotypes in hybrid combinations and assists in the selection of promising parental genotypes and their hybrids in wheat (Rashid et al., 2012; Afridi, 2016; Fasahat et al., 2016). Combining ability is a useful indirect selection criterion for parental cultivars to be used in the hybridization program. It provides information concerning the genetic mechanism of various major and minor genes that cumulatively control yield-related variables in wheat (Kumar et al., 2018; Farooq et al., 2019). Knowledge of combining ability is helpful in the identification of genotypes for promising cross combinations and understanding of inheritance involved in various quantitative traits of wheat (Afridi et al., 2017b).

Line by tester technique is an effective tool and has been widely used to assess different parental populations for combining ability, gene action, and to select promising genotypes for developing new wheat cultivars (Tiwari et al., 2017; Rajput, 2019). Combining ability can be divided into general combining ability (GCA) which is due to the additive type of gene action while specific combining ability (SCA) indicates the dominant gene action (Sprague and Tatum, 1942; Younas et al., 2020). For breeding programs aiming at hybridization, information about better combiners possessing desirable traits is a pre-requisite. For improvement in grain yield and its contributing traits, the plant breeders always focus on the development of high yielding wheat cultivars by crossing best general combiners and to select desirable transgressive segregants from resulting hybrids.

In Pakistan, the efforts in wheat breeding remain focused on enhancing the resistance to rust and production (Minhas et al., 2014; Ahmad et al., 2017). Due to significant achievements in plant breeding, many crop cultivars have been developed with greater genetic potential for high yield and the production of crops has been tremendously increased all over the world. Wheat yield has been significantly enhanced through the development of promising genotypes worldwide (Saeed and Khalil, 2017). During 2018-19, the area of 8.678 million hectares was under wheat crop and 24.349 million tons of grains produced with a mean production of $2806 \mathrm{~kg} \mathrm{ha}^{-1}$ in Pakistan (Anonymous, 2018-19).

Development of new productive genotypes by hybridizing the genotypes with good GCA for the traits of interest and selecting the vigorous hybrids remained the main objective of the breeders. Information about diallel analysis and various gene actions is essential to promote a standard breeding program as it provides basis about the genetic pattern of inheritance controlling different traits in wheat (Murugan and Kannan, 2017; Dhoot et al., 2020). In plant breeding, the genetic analysis and combining ability have an important role in the identification and selection of promising parental genotypes and their hybrids for improvement in various quantitative traits of wheat (Istipliler et al., 2015; Abro et al., 2016; Rajput and Kandalkar, 2018). Past research enunciated that grain yield and its component traits were controlled by additive gene action in wheat (Ismail 2015; Khiabani et al., 2015; Kandil et al., 2016; Rahul, 2017; Adhikari et al., 2020). However, some investigations revealed that morphological, maturity, and yield variables were managed by dominant gene action in wheat (Ingle et al., 2018; Sattar et al., 2018; Sharma et al., 2019; Ayoob, 2020)

Keeping in view the above consideration, the current research was conducted to determine, a) genetic variability, b) GCA and SCA of parental genotypes and their $\mathrm{F}_{2}$ populations, respectively, c) gene action controlling various traits, and d) superior populations that might be used in future for further improvement in wheat.

\section{MATERIALS AND METHODS}

Genetic Material, Experimental Design, and Procedure: The present research was carried out during 2015-2018 at the Cereal Crops Research Institute (CCRI), Pirsabak - Nowshera, Pakistan (situated between $34^{\circ} \mathrm{N}$ latitude and $72^{\circ} \mathrm{E}$ longitude, at an altitude of $288 \mathrm{~m}$ ). The study site soil was sandy-loam with $\mathrm{pH}(7.7)$, organic matter $(0.33 \%), \mathrm{N}(0.016 \%), \mathrm{P}_{2} \mathrm{O}_{5}(4.00 \mathrm{ppm})$, and $\mathrm{K}_{2} \mathrm{O}$ $(85.00 \mathrm{ppm})$. Six wheat lines i.e., IBWSN-177, IBWSN52, IBWSN131, SRN-09111, PR-107, and NR-21, and three testers i.e., Pakhtunkhwa-15, Pirsabak-15, and Shahkar-13 were grown and crossed during 2015-16 in a line by tester matting design (Table 1). During 2016-17, the generation of the breeding material is advanced in Northern Hilly Areas for leaf rust screening. During 2017-18, eighteen $F_{2}$ populations along their nine parental lines and testers were grown and evaluated in a randomized complete block design with three replications. All the populations were grown in a plot size of $5 \times 1.20 \mathrm{~m}^{2}$, having four rows of five-meter length, with 10 and $30 \mathrm{~cm}$ plant and row spacing, respectively.

Crop Husbandry: During three years of studies before seed bed preparation, the fields were well irrigated to create conditions conducive for seedbed preparation. The field was ploughed with deep plough then harrowed with planking each time to make the soil loose, fine, leveled, and pulverized. The fertilizers were used at the rate of 120:90:60 NPK kg ha-1. All $\mathrm{P}_{2} \mathrm{O}_{5}, \mathrm{~K}_{2} \mathrm{O}$, and half $\mathrm{N}$ were applied at the time of planting and the residual partly $\mathrm{N}$ was used in two split doses with first and second irrigations. Sowing was carried out during the second week of November. In parental genotypes and their $F_{2}$ 
populations, the single seed per hill was planted. Four irrigations were given to the crop until maturity. The dominant weeds observed in the field were Avena fatua, Chenopodium album, Chenopodium murale, Convolvulus arvensis, Cynodon dactylon, Phalaris minor, and Rumex dentatus. The broad and narrow-leaved weeds were controlled with Buctril Super (Bromoxynil, $750 \mathrm{ml} \mathrm{ha}^{-1}$ ) and Puma Super (Fenoxaprop-P-ethyl $69 \mathrm{~g}, 1250 \mathrm{ml} \mathrm{ha}^{-}$ $\left.{ }^{1}\right)$, respectively. However, the leftover weed plants were removed manually. The randomly selected plants were harvested on a single plant basis and used for the data recording separately after threshing.

Data Recorded: Data were recorded on days to heading, plant height, flag leaf area, fertile tillers per plant, grain yield per plant (g), and harvest index per plant (g) using randomly selected 20 plants in parental cultivars and $F_{2}$ populations. Days to heading were taken from the sowing date to the date of $50 \%$ heading. The plant height $(\mathrm{cm})$ was measured by using a meter rod from the ground surface to the tip of the spike of the main stem excluding awns. Flag leaf area was measured according to formula i.e., leaf area $=$ length $\times$ breadth $\times 0.75$ (Quarrie and Jones, 1979). From randomly selected plants, the fertile tillers per plant were counted and averaged for further analysis. All the plants were harvested and threshed on a single plant basis. By weighing the grains of 20 plants in parents and $\mathrm{F}_{2}$ populations, and then averaged for getting grain yield per plant $(\mathrm{g})$. The harvest index was calculated in each genotype by dividing grain yield with biological yield.

Biometrical Analysis: All the data for various traits was analyzed according to Steel et al. (1997). The least significant difference $\left(\mathrm{LSD}_{0.05}\right)$ test was used for comparison and separation of population means for each variable. Upon getting significant variations among populations, line by tester combining ability analysis was carried out to ascertain the variances and effects due to general and specific combining ability and gene action for various traits in wheat (Kempthorne, 1957; Singh and Chaudhary, 1985). The variances due to GCA $\left(\sigma^{2}{ }_{\mathrm{GCA}}\right)$, SCA $\left(\sigma_{\mathrm{SCA}}^{2}\right)$, additive $\left(\sigma_{\mathrm{A}}^{2}\right)$ and dominance $\left(\sigma_{\mathrm{D}}^{2}\right)$ components, and proportional contribution of lines, testers, and line by tester $F_{2}$ populations to the total variance were calculated.

\section{RESULTS}

Analysis of variance revealed significant $(p \leq 0.01)$ variations among the genotypes (parental cultivars and $F_{2}$ populations) for all the studied traits (Table 2). Genotypes revealed greater genetic discrepancies and room for further improvement. The genetic variation detected in parent cultivars and $F_{2}$ populations was further distributed into constituents of combining ability (GCA, SCA) through line-by-tester analysis.

\section{Genetic Variability among Parent Cultivars and Line $\times$ Tester $F_{2}$ Populations}

Days to Heading: In lines, days to heading ranged from 114.0 (SRN-09111) to 121.0 days (IBWSN-177), testers varied from 117.0 (Shahkar-13) to 120.0 days (Pirsabak15), while their $F_{2}$ populations ranging from 113.7 $($ IBWSN-177 $\times$ Pirsabak-15) to 123.0 days (NR-21 $\times$ Pirsabak-15) (Table 3). On average, $F_{2}$ populations took fewer days to heading (117.1 days) compared to lines (117.8 days) and testers (118.7 days). In lines, minimum days to heading were observed in SRN-09111 (114.0 days), followed by PR-107 (115.0 days) while maximum in IBWSN-177 (121.0 days). In testers, the least number of days to heading were recorded in Shahkar-13 (117.0 days), followed by Pakhtunkhwa-15 (119.0 days) and Pirsabak-15 (120.0 days). Overall, the $\mathrm{F}_{2}$ population IBWSN-177 $\times$ Pirsabak-15 took minimum days to heading (113.7 days), followed by IBWSN-52 $\times$ Pakhtunkhwa-15 (114.7 days) and line SRN-09111 (114.0 days). The $F_{2}$ population NR-21 $\times$ Pirsabak-15 attained the utmost days to heading (123.0 days), pursued by lines IBWSN-177 (121.0 days), IBWSN-52 (120.3 days) and tester Pirsabak-15 (120.0 days). Other genotypes exhibited a medium number of days to heading. These promising genotypes were considered as early flowering which can be utilized in the development of early maturing wheat genotypes.

Plant Height: Among lines, plant height varied between 90.1 (IBWSN-177) and $96.4 \mathrm{~cm}$ (SRN-09111), among testers, it ranged from 95.4 (Shahkar-13) to $100.5 \mathrm{~cm}$ (Pirsabak-15) while in $\mathrm{F}_{2}$ populations, it was ranging from $89.1($ SRN-09111 $\times$ Shahkar-13) to $99.5 \mathrm{~cm}$ (IBWSN-177 × Pakhtunkhwa-15) (Table 3). On average, the $F_{2}$ population revealed less plant height $(95.9 \mathrm{~cm})$ than testers $(97.7 \mathrm{~cm})$ but more than lines $(93.6 \mathrm{~cm})$. Overall, the least and desirable plant height was recorded in $F_{2}$ population SRN-09111 $\times$ Shahkar-13 $(89.1 \mathrm{~cm})$, followed by line IBWSN-177 $(90.1 \mathrm{~cm})$ and $\mathrm{F}_{2}$ population NR-21 $\times$ Pakhtunkhwa-15 $(91.6 \mathrm{~cm})$. Line IBWSN-177 revealed the least plant stature $(90.1 \mathrm{~cm})$, followed by IBWSN-131 $(92.1 \mathrm{~cm})$ while maximum plant height attained in line SRN-09111 $(96.4 \mathrm{~cm})$. In testers, Shahkar-13 showed less plant height $(95.4 \mathrm{~cm})$, followed by Pakhtunkhwa-15 $(97.1 \mathrm{~cm})$. Overall, maximum plant height was recorded in tester Pirsabak-15 $(100.5 \mathrm{~cm})$, followed by IBWSN-177 $\times$ Pakhtunkhwa-15 $(99.5 \mathrm{~cm})$. Other genotypes showed a medium plant stand. These promising populations could be utilized as source material to minimize the plant height in wheat genotypes through future breeding programs.

Flag Leaf Area: In lines, the flag leaf area ranged from 25.8 (IBWSN-131) to $32.3 \mathrm{~cm}^{2}$ (NR-21), in testers varied 
from 28.3 (Pakhtunkhwa-15) and $35.8 \mathrm{~cm}^{2}$ (Shahkar-13) while in $\mathrm{F}_{2}$ populations, it varied from 26.1 (IBWSN-131 $\times$ Pirsabak-15) to $37.0 \mathrm{~cm}^{2}$ (IBWSN-52 $\times$ Pakhtunkhwa15) (Table 3). On average, the $F_{2}$ population exhibited increased flag leaf area $\left(31.0 \mathrm{~cm}^{2}\right)$ compared to lines $\left(29.3 \mathrm{~cm}^{2}\right)$ but less than testers $\left(32.2 \mathrm{~cm}^{2}\right)$. According to lines, the enhanced flag leaf area was recorded in line NR-21 $\left(32.3 \mathrm{~cm}^{2}\right)$, followed by IBWSN-177 $\left(29.9 \mathrm{~cm}^{2}\right)$ while less estimate was recorded in line IBWSN-131 $\left(25.8 \mathrm{~cm}^{2}\right)$. Regarding testers, Shahkar-13 was observed with an increased flag leaf area $\left(35.8 \mathrm{~cm}^{2}\right)$, followed by Pirsabak-15 (32.4 $\left.\mathrm{cm}^{2}\right)$ and Pakhtunkhwa-15 $\left(28.3 \mathrm{~cm}^{2}\right)$. Overall, the maximum and desirable flag leaf area was observed in $\mathrm{F}_{2}$ population IBWSN-52 $\times$ Pakhtunkhwa-15 $\left(37.0 \mathrm{~cm}^{2}\right)$, followed by IBWSN-177 $\times$ Shahkar-13 and tester Shahkar-13 with the same value $\left(35.8 \mathrm{~cm}^{2}\right)$. However, the minimum flag leaf area was observed in line IBWSN-131 $\left(25.8 \mathrm{~cm}^{2}\right)$, followed by $\mathrm{F}_{2}$ population IBWSN-131 $\times$ Pirsabak-15 $\left(26.1 \quad \mathrm{~cm}^{2}\right)$. All other genotypes revealed medium measurements for the flag leaf area. Genotypes with maximum flag leaf area are preferred in wheat breeding because it contributes to grain yield with greater potential. Therefore, the $F_{2}$ populations i.e., IBWSN-52 × Pakhtunkhwa-15, IBWSN$177 \times$ Shahkar-13, and tester Shahkar-13 can be utilized in future wheat breeding programs.

Tillers per Plant: For tillers per plant, lines varied from 9.1 (IBWSN-177) to 13.7 (SRN-09111), while testers ranged from 8.66 (Pirsabak-15) to 14.6 (Shahkar-13) (Table 3). In $F_{2}$ populations, the range for the said trait was 8.7 (PR-107 × Pirsabak-15) and 14.4 (IBWSN-177 $\times$ Pakhtunkhwa-15). On average and by comparing with lines (11.3) and testers (11.7), the $\mathrm{F}_{2}$ populations showed more tiller per plant (12.1). Among lines, the increased number of tillers was noted in line SRN-09111 (13.7), followed by IBWSN-52 (12.0), while the least tillers per plant were recorded in line IBWSN-177 (9.1). According to testers, the higher number of tillers were counted in tester Shahkar-13 (14.6), followed by Pakhtunkhwa-15 (11.7), while minimum in Pirsabak-15 (8.7). Overall, the maximum number of tillers were recorded in $F_{2}$ populations i.e., IBWSN-177 × Pakhtunkhwa-15 (14.4) and PR-107 $\times$ Shahkar-13 (14.1) and tester Shahkar-13 (14.6). However, the minimum and the same number of tillers per plant (8.7) were observed in tester Pirsabak-15 and $\mathrm{F}_{2}$ population PR-107 $\times$ Pirsabak-15, followed by IBWSN-52 × Pakhtunkhwa-15 (8.8). All other genotypes exhibited a medium number of tillers. Grain yield comprised of the combined production of the main stem and secondary tillers per plant. Therefore, these promising genotypes can be used for the development of the wheat genotypes with an enhanced number of tillers.

Grain Yield per Plant: For grain yield, the lines, testers and $F_{2}$ populations varied from 21.9 (NR-21) to $29.5 \mathrm{~g}$ (IBWSN-52), 19.2 (Pirsabak-15) and $27.6 \mathrm{~g}$
(Pakhtunkhwa-15), and $22.7 \quad($ SRN-09111 $\times$ Pakhtunkhwa-15) to 30.4 g (IBWSN-131 $\times$ Pakhtunkhwa-15) (Table 3). On average, the $F_{2}$ populations produced more grain yield (26.5 g) compared to lines $(25.5 \mathrm{~g})$ and testers $(23.2 \mathrm{~g})$. In lines, the enhanced grain yield was produced by line IBWSN-52 (29.5 g), followed by PR-107 (28.2 g) while the least grain yield was achieved in line NR-21 (21.9 g). The increased grain yield was obtained in tester Pakhtunkhwa-15 (27.6 g), followed by Shakar-13 (22.7 g). Overall, the highest grain yield was recorded in $\mathrm{F}_{2}$ population IBWSN-131 × Pakhtunkhwa-15 (30.4 g), followed by IBWSN-131 $\times$ Shahkar-13 (30.0 g) and PR107 × Shahkar-13 (29.95 g). However, the least grain yield was attained in tester Pirsabak-15 (19.2 g), followed by line NR-21 (21.9 g) and $F_{2}$ population SRN-09111 $\times$ Pakhtunkhwa-15 (22.7 g). All other genotypes showed medium estimates for grain yield per plant. Grain yield is a complex trait and its variation managed by yield contributing traits. Therefore, $\mathrm{F}_{2}$ populations i.e., IBWSN-131 × Pakhtunkhwa-15, IBWSN-131 × Shahkar13 , and PR107 $\times$ Shahkar-13 can be advanced for further improvement in grain yield.

Harvest Index: Harvest index varied from 32.3 (IBWSN-177) to $43.6 \%$ (PR-107) among lines, 31.1 (Shahkar-13) to $41.1 \%$ (Pakhtunkhwa-15) among testers, while in $\mathrm{F}_{2}$ populations the said range was 28.2 (IBWSN$177 \times$ Shahkar-13) to $47.6 \%$ (IBWSN-131 $\times$ Pakhtunkhwa-15) (Table 3). On average, the $F_{2}$ populations provided more harvest index $(37.5 \%)$ by comparing to lines $(37.0 \%)$ and testers $(34.8 \%)$. Line PR107 showed the highest harvest index $(43.6 \%)$, followed by IBWSN-52 $(40.4 \%)$ while the least percentage shown by IBWSN-177 (32.3\%). In testers, the maximum harvest index revealed by tester Pakhtunkhwa-15 (41.1\%), while the least percentages of harvest index were recorded in Pirsabak-15 (32.3\%) and Shahkar-13 (31.1\%). Overall, the maximum harvest index was observed in $\mathrm{F}_{2}$ population IBWSN-131 $\times$ Pakhtunkhwa-15 (47.6\%), followed by line PR-107 (43.6\%). However, $\mathrm{F}_{2}$ population IBWSN-177 $\times$ Shahkar-13 $(28.2 \%)$, followed by tester Shahkar-13 (31.1\%) showed a minimum harvest index. Other genotypes showed medium percentages for harvest index. Genotypes with increased harvest index are preferred to select, therefore, the genotypes IBWSN$131 \times$ Pakhtunkhwa-15 and PR-107 could be utilized for enhancement in harvest index and grain yield.

Line $\times$ Tester Analysis: According to combining ability analysis, lines revealed significant $(\mathrm{p} \leq 0.01)$ variations for days to heading and harvest index, merely significant $(\mathrm{p} \leq 0.05)$ for plant height and flag leaf area, and nonsignificant for tillers per plant and grain yield per plant (Table 2). Testers revealed nonsignificant variations for all the studied traits. However, line by tester 
interactions were significant $(\mathrm{p} \leq 0.01)$ for all the variables.

General and Specific Combining Ability Effects: For days to heading, in lines, GCA ranged from -1.57 to 2.98 (Table 4). Three lines i.e., IBWSN-177, IBWSN-52, and IBWSN-131 expressed the negative and desirable GCA while the remaining three lines (SRN-09111, PR-107, and NR-21) revealed positive GCA for days to heading. The highest negative and desirable GCA was observed in line IBWSN-177 (-1.57) while the line NR-21 (2.98) exhibited maximum positive GCA. In testers, for days to heading the GCA ranged from -0.63 to 0.70 . The highest negative and desirable GCA was observed in tester Pakhtunkhwa-15 (-0.63), followed by Shahkar-13 (-0.07), while tester Pirsabak-15 (0.70) revealed maximum positive GCA. Overall, the desirable and significant negative GCA was recorded in line IBWSN-177, followed by two other lines IBWSN-52 and IBWSN-131, and were considered as the best general combiners for earliness which can be employed in the future breeding program.

In lines, for days to heading the SCA varied from -2.59 to 2.19 (Table 5). Half of the $F_{2}$ populations revealed negative and desirable SCA ranging from -2.59 to -0.15 while the other half revealed positive SCA $(0.07$ to 2.19). Highly significant negative SCA was observed in $\mathrm{F}_{2}$ population IBWSN-177 $\times$ Pirsabak-15 (-2.59), followed by SRN-09111 $\times$ Pakhtunkhwa-15 (-2.26) and NR-21 $\times$ Shahkar-13 (-2.04). Genotypes with significant negative SCA are preferred to be utilized in the development of early maturing genotypes which can escape from the late-season biotic and abiotic stresses. Results further depicted that high $\times$ low and low $\times$ low GCA parents were involved in the performance of promising $\mathrm{F}_{2}$ populations. Therefore, $\mathrm{F}_{2}$ populations IBWSN-177 $\times$ Pirsabak-15, SRN-09111 $\times$ Pakhtunkhwa15, and NR-21 $\times$ Shahkar-13 were identified as promising specific combinations.

Among lines for plant height, the GCA varied from -2.83 to 2.57 (Table 4). Two Lines SRN-09111 and NR-21 revealed negative and desirable GCA while four other lines i.e., IBWSN-177, IBWSN-52, IBWSN-131, and PR-107 revealed positive GCA. The utmost negative and desirable GCA was attained by line SRN-09111 (2.83), while the highest positive GCA was exhibited by line IBWSN-177 (2.57). In testers, GCA ranged from 0.30 to 0.53 for plant height. The maximum negative and desirable GCA was displayed by tester Pirsabak-15 (0.30 ), while the highest positive GCA was recorded in tester Pakhtunkhwa-15 (0.53). Overall, the highest negative GCA was recorded in line SRN-09111, followed by NR-21 and were believed to be the best general combiners for the said variable.

The SCA estimates varied from -3.77 to 3.14 for plant height (Table 5). Half of the $F_{2}$ populations were found with negative SCA ranging from -3.77 to -0.15 while the other half showed positive SCA (0.08 to 3.14). The $F_{2}$ populations i.e., SRN-09111 $\times$ Shahkar-13 (-3.77) and NR-21 $\times$ Pakhtunkhwa-15 (-2.58) possessed maximum negative SCA while positive SCA obtained in NR-21 $\times$ Shahkar-13 (3.14) and SRN-09111 $\times$ Pakhtunkhwa-15 (2.15). For plant height, the negative combining ability is favored because the short stature genotypes have fewer chances of lodging and more responsive to fertilizers. Present investigations highlighted that high $\times$ low general combiners were more important in $\mathrm{F}_{2}$ populations with desirable SCA and paramount performance. Therefore, $\mathrm{F}_{2}$ populations SRN$09111 \times$ Shahkar-13 and NR-21 $\times$ Pakhtunkhwa-15 were considered as best specific combiners for plant height which can be utilized in breeding as dwarfing gene sources.

For the flag leaf area, lines GCA varied from 2.35 to 3.90 (Table 4). Two lines IBWSN-177 and IBWSN-52 showed positive GCA while four other lines (IBWSN-131, SRN-09111, PR-107, and NR-21) exhibited negative GCA. The highest positive GCA was recorded in line IBWSN-177 (3.90) while the lowest and negative GCA was attained in line IBWSN-131 (-2.35). In testers, GCA was ranging from -1.16 to 0.80 for the flag leaf area. Two testers Pakhtunkhwa-15 and Shahkar13 showed positive GCA while tester Pirsabak-15 showed negative GCA estimates for flag leaf area. Among testers, Shahkar-13 revealed maximum positive GCA (0.80) while the tester Pirsabak-15 showed the maximum negative GCA (-1.16). Overall, line IBWSN177 showed the highest positive GCA (3.90), followed by IBWSN-52 (1.67) and were considered as the best general combiners for the said trait.

In $\mathrm{F}_{2}$ populations, $\mathrm{SCA}$ ranged from -2.90 to 4.02 for the flag leaf area (Table 5). The SCA estimates revealed that half of the $\mathrm{F}_{2}$ populations were found to have positive SCA (0.16 to 4.02) while the other half showed negative SCA (-2.90 to -0.22$)$ for flag leaf area. The highest positive SCA was recorded in $\mathrm{F}_{2}$ population IBWSN-52 × Pakhtunkhwa-15 (4.02), followed by NR$21 \times$ Shahkar-13 (2.74). However, the highest negative SCA was attained by $\mathrm{F}_{2}$ population NR-21 $\times$ Pakhtunkhwa-15 (-2.90), followed by IBWSN-52 $\times$ Pirsabak-15 (-2.81). The $\mathrm{F}_{2}$ populations IBWSN-52 $\times$ Pakhtunkhwa-15 and NR-21 $\times$ Shahkar-13 were identified as the greatest specific combinations for the flag leaf area. Results further revealed that high $\times$ low and low $\times$ low general combiners were involved in promising $F_{2}$ populations for flag leaf area. Therefore, these prominent genotypes could be used in future breeding for improvement in morphological traits.

In lines, the GCA differed from -1.33 to 0.60 for tillers per plant (Table 4). Three lines IBWSN-177, IBWSN-131, and SRN-09111 were recorded with positive GCA estimates while the other three lines 
exhibited IBWSN-52, PR-107 and NR-21 showed negative GCA. The highest positive and same GCA $(0.60)$ was recorded in two lines IBWSN-177 and SRN09111. However, the highest negative GCA was attained by line IBWSN-52 (-1.33). In testers, the GCA varied from -1.04 to 0.82 for tillers per plant. Two testers Shakar-13 and Pakhtunkhwa-15 exhibited positive GCA while tester Pirsabak-15 showed negative GCA. The tester Shahkar-13 showed significant positive GCA (0.82), while Pirsabak-15 exhibited the highest negative GCA (-1.04). Overall, significant positive GCA estimations were achieved by tester Shahkar-13, followed by lines IBWSN-177 and SRN-09111, and believed to be prominent general combiners for improving tillers capacity.

In $F_{2}$ populations, the SCA estimates varied from -2.15 to 1.64 for tillers per plant (Table 5). Ten $\mathrm{F}_{2}$ populations exposed positive SCA (ranged from 0.11 to 1.64) while eight other $F_{2}$ populations exhibited negative SCA (varied from -2.15 to -0.32 ). The $\mathrm{F}_{2}$ populations IBWSN-52 $\times$ Pirsabak-15, PR-107 $\times$ Shahkar-13, and NR-21 $\times$ Pakhtunkhwa-15 showed the utmost positive SCA i.e., 1.64, 1.63 and 1.54, respectively. However, the highest negative SCA was attained by $\mathrm{F}_{2}$ population IBWSN-52 $\times$ Pakhtunkhwa-15 (-2.15), followed by PR$107 \times$ Pirsabak-15 (-1.93) and IBWSN-177 $\times$ Shahkar-13 $(-1.62)$. Low $\times$ low and low $\times$ high general combiners were involved in promising $\mathrm{F}_{2}$ populations for the said trait. The $\mathrm{F}_{2}$ populations IBWSN-52 $\times$ Pirsabak-15, PR$107 \times$ Shahkar-13, and NR-21 $\times$ Pakhtunkhwa-15 could be used as best specific combiners for enhancement in tillers per plant.

For grain yield, lines GCA varied from -1.15 to 2.54 (Table 4). Two lines IBWSN-52 and IBWSN-131 recorded with positive GCA while four other lines IBWSN-177, SRN-09111, PR-107, and NR-21 showed negative GCA. Highly significant positive GCA was achieved by line IBWSN-131 (2.54), while the highest negative GCA was exhibited by line SRN-09111 (-1.15). In testers, GCA varied from -0.62 to 1.19 for grain yield. Tester cultivar Shahkar-13 revealed positive GCA estimates while two other testers Pakhtunkhwa-15 and Pirsabak-15 recorded with negative GCA. The highest positive GCA was noted in tester Shahkar-13 (1.19), whereas the maximum negative GCA was attained by tester Pakhtunkhwa-15 (-0.62). Overall, based on GCA the line IBWSN-131 and tester Shahkar-13 were regarded as best general combiners for grain yield.

In $F_{2}$ population, $S C A$ diverged from -3.02 to 2.81 for grain yield (Table 5). Eight $\mathrm{F}_{2}$ populations were recorded with positive SCA varied from 0.25 to 2.81 whereas ten $\mathrm{F}_{2}$ populations recorded with negative SCA $(-3.02$ to -0.10$)$. The highest positive SCA was found in $\mathrm{F}_{2}$ populations PR-107 $\times$ Shahkar-13 (2.81), IBWSN-131 $\times$ Pakhtunkhwa-15 (2.01), and IBWSN-177 $\times$ Pirsabak15 (1.93). The utmost negative SCA was attained by $F_{2}$ populations IBWSN-177 $\times$ Shahkar-13 (-3.02), and SRN$09111 \times$ Pakhtunkhwa-15 (-2.03). Grain yield is an intricate variable and its variance controlled by yield contributing traits. Results authenticated that low $\times$ high and high $\times$ low and low $\times$ low general genotypes were involved in promising $\mathrm{F}_{2}$ populations for grain yield. The talented $\mathrm{F}_{2}$ populations PR-107 $\times$ Shahkar-13, ISWBN$131 \times$ Pakhtunkhwa-15, and IBWSN-177 $\times$ Pirsabak-15 could be further exploited for improvement in grain yield.

In the case of harvest index, lines GCA varied from -5.55 to 4.18 (Table 4). Half of the lines IBWSN177, IBWSN-52, and IBWSN-131 exhibited positive GCA whereas other half SRN-09111, PR-107, and NR21 revealed negative GCA. The highest positive GCA was attained by line IBWSN-52 (4.18) while line SRN$09111(-5.55)$ revealed the utmost negative GCA. Among testers, GCA varied from -1.14 to 0.67 for harvest index. Two testers Pirsabak-15 (0.67) and Pakhtunkhwa-15 (0.47) manifested positive GCA while tester Shahkar-13 showed negative GCA (-1.14). Overall, the highest positive GCA estimates were obtained by lines IBWSN52 (4.18) and IBWSN-131 (4.14) and were considered as best general combiners for harvest index.

In $\mathrm{F}_{2}$ populations, $\mathrm{SCA}$ varied from -4.68 to 5.55 for harvest index (Table 5). Half of the $F_{2}$ populations recorded with positive SCA ranging from 0.51 to 5.55 while the other half showed negative SCA (-4.68 to $0.44)$. The highest positive SCA was revealed by $F_{2}$ population IBWSN-131 $\times$ Pakhtunkhwa-15 (5.55), followed by two other $F_{2}$ populations IBWSN-177 $\times$ Pirsabak-15 (3.14) and SRN-09111 $\times$ Pirsabak-15 (3.08). The highest negative SCA was noted in $\mathrm{F}_{2}$ population IBWSN-177 $\times$ Pakhtunkhwa-15 (-4.68), followed by SRN-09111 $\times$ Pakhtunkhwa-15 (-4.11). High $\times$ low and low $\times$ low GCA parents were used in talented $F_{2}$ populations with the best mean performance for harvest index. The $\mathrm{F}_{2}$ populations IBSWN-131 $\times$ Pakhtunkhwa15, IBSWN-177 $\times$ Pirsabak-15, and SRN-09111 $\times$ Pirsabak-15 were recognized as best specific combinations which can be utilized for further improvement in harvest index.

Gene Action: Comparison of GCA and SCA variance showed that dominant gene action performed an imperative role in the inheritance of all the variables (Table 6). Overall, the variations due to GCA $\left(\sigma^{2}{ }_{\mathrm{GCA}}\right)$ were lower than SCA variances $\left(\sigma^{2} \mathrm{SCA}\right)$ for all the traits, suggesting the predominance role of dominant gene action in controlling these traits. These finding also got support from the ratio of GCA to $\operatorname{SCA}\left(\sigma^{2}{ }_{\mathrm{GCA}} / \sigma^{2} \mathrm{SCA}\right)$ which was lesser than unity ranging from 0.004 to 0.08 and degree of dominance $\left(\sigma^{2} / \sigma^{2} \mathrm{~A}\right)^{1 / 2}$ which was greater than unity ranging from 2.46 to 10.07 . It revealed that the inheritance of all the parameters was managed by dominant gene action. Dominant gene action specified that assortment of better genotypes for improvement, in 
terms of earliness, morphological and yield-related variables, should be delayed to the next generations for further selection.

Proportional Contribution of Genotypes to Total Variance: In proportional contribution to the total variance, the lines had a maximum share for traits i.e., days to heading $(59.45 \%)$, plant height $(60.39 \%)$, flag leaf area (54.96\%) and harvest index (61.97\%) (Table 7). For tiller number $(56.14 \%)$, and grain yield $(47.63 \%)$, the share of line-by-tester $\mathrm{F}_{2}$ populations was leading compared to lines and testers. Present investigations further authenticated that lines and line-by-tester $\mathrm{F}_{2}$ populations were found responsible for playing a vital role in managing the variation in these variables.

Parental lines IBWSN-131, Shahkar-13, and $F_{2}$ populations IBWSN-131 × Pakhtunkhwa-15, IBWSN$131 \times$ Shahkar-13, and PR107 $\times$ Shahkar-13 were identified as prominent general and specific combinations, correspondingly and performed better for earliness and yield traits. High $\times$ high, high $\times$ low and low $\times$ high GCA parental cultivars were concerned in the presentation of $\mathrm{F}_{2}$ populations with promising SCA and best mean performance. The ratios of GCA to SCA variances and the degree of dominance were smaller and greater than unity, respectively which confirmed that all the traits were managed by dominant gene action.

Table 1. Parental genotypes and their $F_{2}$ populations used in the studies.

\begin{tabular}{|c|c|c|c|}
\hline S. No. & Parental genotypes & S. No. & $F_{2}$ Populations \\
\hline Lines & & 4 & IBWSN-52 × Pakhtunkhwa-15 \\
\hline 1 & IBWSN-177 & 5 & IBWSN-52 × Pirsabak-15 \\
\hline 2 & IBWSN-52 & 6 & IBWSN-52 × Shahkar-13 \\
\hline 3 & IBWSN-131 & 7 & IBWSN-131 × Pakhtunkhwa-15 \\
\hline 4 & SRN-09111 & 8 & IBWSN-131 × Pirsabak-15 \\
\hline 5 & PR-107 & 9 & IBWSN-131 × Shahkar-13 \\
\hline 6 & NR-21 & 10 & SRN-09111 × Pakhtunkhwa-15 \\
\hline Testers & & 11 & SRN-09111 × Pirsabak-15 \\
\hline 1 & Pakhtunkhwa-15 & 12 & SRN-09111 × Shahkar-13 \\
\hline 2 & Pirsabak-15 & 13 & PR-107 × Pakhtunkhwa-15 \\
\hline 3 & Shahkar-13 & 14 & PR-107 × Pirsabak-15 \\
\hline \multicolumn{2}{|c|}{$F_{2}$ Populations } & 15 & PR-107 × Shahkar-13 \\
\hline 1 & IBWSN-177 × Pakhtunkhwa-15 & 16 & NR-21 $\times$ Pakhtunkhwa-15 \\
\hline 2 & IBWSN-177 × Pirsabak-15 & 17 & NR-21 × Pirsabak-15 \\
\hline 3 & IBWSN-177 × Shahkar-13 & 18 & NR-21 $\times$ Shahkar-13 \\
\hline
\end{tabular}

Table 2. Mean squares for various traits in line $\times$ tester combining ability analysis in wheat.

\begin{tabular}{|c|c|c|c|c|c|c|c|}
\hline Source of variation & d.f. & $\begin{array}{l}\text { Days to } \\
\text { heading }\end{array}$ & $\begin{array}{l}\text { Plant } \\
\text { height }\end{array}$ & $\begin{array}{l}\text { Flag leaf } \\
\text { area }\end{array}$ & $\begin{array}{l}\text { Tillers } \\
\text { plant }^{-1}\end{array}$ & $\begin{array}{l}\text { Grain yield } \\
\text { plant }^{-1}\end{array}$ & $\begin{array}{l}\text { Harvest index } \\
\text { plant }^{-1}\end{array}$ \\
\hline Replications & 2 & 1.53 & 4.90 & 13.35 & 0.41 & 4.08 & 9.91 \\
\hline Genotypes & 26 & $15.95^{* *}$ & $21.79^{* *}$ & $25.56^{* *}$ & $8.91^{* *}$ & $22.48^{* *}$ & $63.71^{* *}$ \\
\hline Parents & 8 & $17.42^{* *}$ & $26.79^{* *}$ & $24.76^{*}$ & $11.12^{* *}$ & $33.85^{* *}$ & $69.72^{* *}$ \\
\hline Parents vs. Crosses & 1 & $17.34^{* *}$ & $16.85^{\mathrm{NS}}$ & $8.77^{\mathrm{NS}}$ & $7.17^{* *}$ & $55.78^{* *}$ & $26.40^{*}$ \\
\hline Crosses & 17 & $15.18^{* *}$ & $19.74^{* *}$ & $26.93^{* *}$ & $7.97^{* *}$ & $15.17^{* *}$ & $63.08^{* *}$ \\
\hline Lines & 5 & $30.69^{* *}$ & $40.52^{*}$ & $50.32^{*}$ & $5.33^{\mathrm{NS}}$ & $19.29^{\mathrm{NS}}$ & $132.90^{* *}$ \\
\hline Testers & 2 & $8.07^{\mathrm{NS}}$ & $3.83^{\mathrm{NS}}$ & $19.07^{\mathrm{NS}}$ & $16.38^{\mathrm{NS}}$ & $19.28^{\mathrm{NS}}$ & $17.78^{\mathrm{NS}}$ \\
\hline Lines vs. Testers & 10 & $8.85^{* *}$ & $12.52^{* *}$ & $16.80^{* *}$ & $7.60^{* *}$ & $12.28^{* *}$ & $37.23^{* *}$ \\
\hline Error & 52 & 1.69 & 4.66 & 3.30 & 0.96 & 2.21 & 6.06 \\
\hline C.V.\% & - & 1.1 & 2.26 & 5.92 & 8.28 & 5.74 & 6.64 \\
\hline
\end{tabular}

${ }^{*},{ }^{* *}=$ Significant at $\mathrm{p} \leq 0.05$ and $\mathrm{p} \leq 0.01$, respectively, $\mathrm{NS}=$ Nonsignificant, C.V. $=$ Coefficient of variation 
Table 3. Mean performance of lines, testers, and $F_{2}$ populations for various traits in wheat.

\begin{tabular}{|c|c|c|c|c|c|c|}
\hline $\begin{array}{l}\text { Lines, Testers } \\
\text { and } F_{2} \text { Populations }\end{array}$ & $\begin{array}{l}\text { Days to heading } \\
\text { (days) }\end{array}$ & $\begin{array}{l}\text { Plant } \\
\text { height }(\mathrm{cm})\end{array}$ & $\begin{array}{l}\text { Flag leaf } \\
\text { area }\left(\mathrm{cm}^{2}\right)\end{array}$ & $\begin{array}{l}\text { Tillers } \\
\text { plant }^{-1}\end{array}$ & $\begin{array}{l}\text { Grain yield } \\
\text { plant }^{-1}(\mathrm{~g})\end{array}$ & $\begin{array}{l}\text { Harvest index } \\
\text { plant }^{-1}(\%)\end{array}$ \\
\hline \multicolumn{7}{|l|}{ Lines } \\
\hline IBWSN-177 & 121.0 & 90.1 & 29.9 & 9.1 & 23.4 & 32.3 \\
\hline IBWSN-52 & 120.3 & 93.7 & 29.5 & 12.0 & 29.5 & 40.4 \\
\hline IBWSN-131 & 117.7 & 92.1 & 25.8 & 11.2 & 26.3 & 32.6 \\
\hline SRN-09111 & 114.0 & 96.4 & 29.5 & 13.7 & 23.9 & 39.7 \\
\hline PR-107 & 115.0 & 95.1 & 28.8 & 10.3 & 28.2 & 43.6 \\
\hline NR-21 & 119.0 & 94.3 & 32.3 & 11.6 & 21.9 & 33.2 \\
\hline Means & 117.8 & 93.6 & 29.3 & 11.3 & 25.5 & 37.0 \\
\hline \multicolumn{7}{|l|}{ Testers } \\
\hline Pakhtunkhwa-15 & 119.0 & 97.1 & 28.3 & 11.7 & 27.6 & 41.1 \\
\hline Pirsabak-15 & 120.0 & 100.5 & 32.4 & 8.7 & 19.2 & 32.3 \\
\hline Shahkar-13 & 117.0 & 95.4 & 35.8 & 14.6 & 22.7 & 31.1 \\
\hline Means & 118.7 & 97.7 & 32.2 & 11.7 & 23.2 & 34.8 \\
\hline \multicolumn{7}{|l|}{$F_{2}$ Populations } \\
\hline IBWSN-177 × Pakhtunkhwa-15 & 117.0 & 99.5 & 34.9 & 14.4 & 25.9 & 33.5 \\
\hline IBWSN-177 $\times$ Pirsabak-15 & 113.7 & 98.1 & 33.9 & 11.7 & 26.7 & 41.6 \\
\hline IBWSN-177 × Shahkar-13 & 116.0 & 98.0 & 35.8 & 11.9 & 23.6 & 38.2 \\
\hline IBWSN-52 $\times$ Pakhtunkhwa-15 & 114.7 & 97.5 & 37.0 & 8.8 & 26.5 & 41.9 \\
\hline IBWSN-52 $\times$ Pirsabak-15 & 116.3 & 95.8 & 28.7 & 11.3 & 27.7 & 41.9 \\
\hline IBWSN-52 $\times$ Shahkar-13 & 115.7 & 98.2 & 32.2 & 12.1 & 28.2 & 41.2 \\
\hline IBWSN-131 × Pakhtunkhwa-15 & 115.0 & 97.9 & 29.5 & 12.0 & 30.4 & 47.6 \\
\hline IBWSN-131 × Pirsabak-15 & 116.0 & 96.8 & 26.1 & 12.1 & 26.7 & 38.5 \\
\hline IBWSN-131 × Shahkar-13 & 116.3 & 96.3 & 30.2 & 13.8 & 30.0 & 38.7 \\
\hline SRN-09111 $\times$ Pakhtunkhwa-15 & 114.7 & 95.8 & 30.5 & 12.5 & 22.7 & 28.3 \\
\hline SRN-09111 × Pirsabak-15 & 119.3 & 94.4 & 31.0 & 12.5 & 25.8 & 35.7 \\
\hline SRN-09111 × Shahkar-13 & 118.7 & 89.1 & 29.6 & 12.9 & 27.6 & 31.8 \\
\hline PR-107 × Pakhtunkhwa-15 & 118.3 & 96.5 & 29.6 & 12.2 & 24.4 & 35.9 \\
\hline PR-107 × Pirsabak-15 & 118.7 & 96.0 & 31.1 & 8.7 & 23.5 & 33.9 \\
\hline PR-107 $\times$ Shahkar-13 & 117.7 & 96.1 & 30.1 & 14.1 & 29.95 & 34.0 \\
\hline NR-21 $\times$ Pakhtunkhwa-15 & 119.3 & 91.6 & 26.5 & 13.8 & 25.4 & 40.4 \\
\hline NR-21 $\times$ Pirsabak-15 & 123.0 & 92.8 & 28.1 & 9.8 & 25.1 & 37.3 \\
\hline NR-21 $\times$ Shahkar-13 & 118.0 & 96.6 & 32.6 & 12.5 & 26.9 & 34.2 \\
\hline Means & 117.1 & 95.9 & 31.0 & 12.1 & 26.5 & 37.5 \\
\hline $\mathrm{LSD}_{0.05}$ & 2.13 & 3.54 & 2.98 & 1.61 & 2.44 & 4.03 \\
\hline
\end{tabular}

Table 4. General combining ability effects among lines and testers for various traits in wheat.

\begin{tabular}{|c|c|c|c|c|c|c|}
\hline Parental genotypes & $\begin{array}{l}\text { Days to } \\
\text { heading }\end{array}$ & $\begin{array}{l}\text { Plant } \\
\text { height }\end{array}$ & $\begin{array}{l}\text { Flag leaf } \\
\text { area }\end{array}$ & $\begin{array}{l}\text { Tillers } \\
\text { plant }^{-1}\end{array}$ & $\begin{array}{l}\text { Grain yield } \\
\text { plant }^{-1}\end{array}$ & $\begin{array}{l}\text { Harvest index } \\
\text { plant }^{-1}\end{array}$ \\
\hline \multicolumn{7}{|l|}{ Lines } \\
\hline IBWSN-177 & $-1.57^{* *}$ & 2.57 & $3.90^{* *}$ & 0.60 & -1.11 & 0.28 \\
\hline IBWSN-52 & $-1.51^{* *}$ & 1.23 & $1.67^{* *}$ & -1.33 & 0.96 & $4.18^{* *}$ \\
\hline IBWSN-131 & $-1.35^{* *}$ & 1.03 & -2.35 & 0.56 & $2.54^{* *}$ & $4.14^{* *}$ \\
\hline SRN-09111 & 0.43 & $-2.83^{* *}$ & -0.63 & 0.60 & -1.15 & -5.55 \\
\hline PR-107 & 1.09 & 0.29 & -0.72 & -0.39 & -0.55 & -2.89 \\
\hline NR-21 & 2.98 & $-2.29^{* *}$ & -1.88 & -0.03 & -0.70 & -0.16 \\
\hline S.E. & 0.43 & 0.72 & 0.61 & 0.33 & 0.50 & 0.82 \\
\hline $\mathrm{CD}_{0.05}$ & 0.88 & 1.46 & 1.23 & 0.66 & 1.01 & 1.67 \\
\hline $\mathrm{CD}_{0.01}$ & 1.18 & 1.96 & 1.65 & 0.89 & 1.35 & 2.24 \\
\hline \multicolumn{7}{|l|}{ Testers } \\
\hline Pakhtunkhwa-15 & $-0.63^{*}$ & 0.53 & 0.36 & 0.22 & -0.62 & 0.47 \\
\hline Pirsabak-15 & 0.70 & -0.30 & -1.16 & -1.04 & -0.57 & 0.67 \\
\hline Shahkar-13 & -0.07 & -0.23 & 0.80 & $0.82^{* *}$ & $1.19^{* *}$ & -1.14 \\
\hline S.E. & 0.31 & 0.51 & 0.43 & 0.23 & 0.35 & 0.58 \\
\hline $\mathrm{CD}_{0.05}$ & 0.62 & 1.03 & 0.87 & 0.47 & 0.71 & 1.18 \\
\hline $\mathrm{CD}_{0.01}$ & 0.84 & 1.39 & 1.17 & 0.63 & 0.96 & 1.58 \\
\hline
\end{tabular}

\footnotetext{
${ }^{*},{ }^{* *}=$ Significant at $\mathrm{p} \leq 0.05$ and $\mathrm{p} \leq 0.01$, respectively, $\mathrm{CD}=$ critical difference, S.E. $=$ Standard error
} 
Table 5. Specific combining ability effects among line by tester $F_{2}$ populations for various traits in wheat.

\begin{tabular}{|c|c|c|c|c|c|c|}
\hline$F_{2}$ Populations & $\begin{array}{l}\text { Days to } \\
\text { heading }\end{array}$ & $\begin{array}{l}\text { Plant } \\
\text { height }\end{array}$ & $\begin{array}{l}\text { Flag leaf } \\
\text { area }\end{array}$ & $\begin{array}{l}\text { Tillers } \\
\text { plant }^{-1}\end{array}$ & $\begin{array}{l}\text { Grain yield } \\
\text { plant }^{-1}\end{array}$ & $\begin{array}{l}\text { Harvest index } \\
\text { plant }^{-1}\end{array}$ \\
\hline IBWSN-177 × Pakhtunkhwa-15 & 2.07 & 0.47 & -0.34 & $1.51^{*}$ & 1.09 & -4.68 \\
\hline IBWSN-177 × Pirsabak-15 & $-2.59^{* *}$ & -0.15 & 0.17 & 0.11 & $1.93^{*}$ & $3.14^{* *}$ \\
\hline IBWSN-177 × Shahkar-13 & 0.52 & -0.32 & 0.17 & -1.62 & -3.02 & 1.54 \\
\hline IBWSN-52 $\times$ Pakhtunkhwa-15 & -0.26 & -0.18 & $4.02^{* *}$ & -2.15 & -0.38 & -0.23 \\
\hline IBWSN-52 × Pirsabak-15 & 0.07 & -1.08 & -2.81 & $1.64^{* *}$ & 0.85 & -0.44 \\
\hline IBWSN-52 × Shahkar-13 & 0.19 & 1.25 & -1.21 & 0.51 & -0.47 & 0.66 \\
\hline IBWSN-131 × Pakhtunkhwa-15 & -0.15 & 0.35 & 0.48 & -0.85 & $2.01^{*}$ & $5.55^{* *}$ \\
\hline IBWSN-131 × Pirsabak-15 & -0.48 & 0.08 & -1.30 & 0.49 & -1.78 & -3.74 \\
\hline IBWSN-131 × Shahkar-13 & 0.63 & -0.43 & 0.82 & 0.36 & -0.24 & -1.81 \\
\hline SRN-09111 × Pakhtunkhwa-15 & $-2.26^{* *}$ & 2.15 & -0.22 & -0.35 & -2.03 & -4.11 \\
\hline SRN-09111 × Pirsabak-15 & 1.07 & 1.62 & 1.79 & 0.91 & 1.02 & $3.08^{*}$ \\
\hline SRN-09111 × Shahkar-13 & 1.19 & $-3.77^{* *}$ & -1.57 & -0.56 & 1.01 & 1.03 \\
\hline PR-107 × Pakhtunkhwa-15 & 0.74 & -0.22 & -1.04 & 0.30 & -0.94 & 0.84 \\
\hline PR-107 × Pirsabak-15 & -0.26 & 0.09 & 1.99 & -1.93 & -1.87 & -1.34 \\
\hline PR-107 × Shahkar-13 & -0.48 & 0.13 & -0.95 & $1.63^{* *}$ & $2.81^{* *}$ & 0.51 \\
\hline NR-21 × Pakhtunkhwa-15 & -0.15 & $-2.58^{*}$ & -2.90 & $1.54^{*}$ & 0.25 & 2.63 \\
\hline NR-21 $\times$ Pirsabak-15 & 2.19 & -0.56 & 0.16 & -1.22 & -0.15 & -0.69 \\
\hline NR-21 × Shahkar-13 & $-2.04^{*}$ & 3.14 & $2.74^{*}$ & -0.32 & -0.10 & -1.93 \\
\hline S.E. & 0.75 & 1.25 & 1.05 & 0.57 & 0.86 & 1.42 \\
\hline C. $D_{0.05}$ & 1.53 & 2.53 & 2.13 & 1.15 & 1.74 & 2.89 \\
\hline C. $\mathrm{D}_{0.01}$ & 2.05 & 3.40 & 2.86 & 1.55 & 2.34 & 3.88 \\
\hline
\end{tabular}

Table 6. Genetic components for various traits in line by tester combining ability analysis in wheat.

\begin{tabular}{lllllll}
\hline $\begin{array}{l}\text { Genetic } \\
\text { Components }\end{array}$ & $\begin{array}{l}\text { Days to } \\
\text { heading }\end{array}$ & $\begin{array}{l}\text { Plant } \\
\text { height }\end{array}$ & $\begin{array}{l}\text { Flag leaf } \\
\text { area }\end{array}$ & $\begin{array}{l}\text { Tillers } \\
\text { plant }^{-1}\end{array}$ & $\begin{array}{l}\text { Grain yield } \\
\text { plant }^{\mathbf{1}}\end{array}$ & $\begin{array}{l}\text { Harvest index } \\
\text { plant }^{-1}\end{array}$ \\
\hline$\Sigma_{\mathrm{GCA}}^{2}$ & 0.19 & 0.22 & 0.30 & 0.01 & 0.09 & 0.78 \\
$\Sigma_{\mathrm{SCA}}^{2}$ & 2.38 & 2.62 & 4.50 & 2.21 & 3.35 & 10.39 \\
$\Sigma_{\mathrm{A}}^{2}$ & 0.37 & 0.43 & 0.61 & 0.02 & 0.17 & 1.55 \\
$\Sigma^{2} \mathrm{D}$ & 2.38 & 2.62 & 4.50 & 2.21 & 3.35 & 10.39 \\
$\Sigma_{\mathrm{GCA}}^{2} / \sigma^{2} \mathrm{SCA}$ & 0.08 & 0.08 & 0.06 & 0.004 & 0.02 & 0.07 \\
{$\left[\sigma_{\mathrm{D}}^{2} / \sigma_{\mathrm{A}}^{2}\right]^{1 / 2}$} & 2.50 & 2.46 & 2.72 & 10.07 & 4.40 & 2.59 \\
\hline
\end{tabular}

$\sigma_{\mathrm{GCA}}^{2}$ GCA variance, $\sigma^{2} \mathrm{SCA}$ : SCA variance, $\sigma^{2} \mathrm{~A}$ : additive genetic variance, $\sigma^{2} \mathrm{D}$ : dominant genetic variance, $\sigma^{2} \mathrm{GCA} / \sigma^{2} \mathrm{SCA}$ : the ratio of GCA to SCA, $\left[\sigma^{2} \mathrm{D} / \sigma^{2} \mathrm{~A}\right]^{1 / 2}$ : the degree of dominance

Table 7. The proportional contribution of lines, testers, and line $\times$ tester $F_{2}$ populations for various traits in wheat.

\begin{tabular}{llll}
\hline Variables & Lines $(\%)$ & Testers $(\%)$ & Line $\times$ Tester $\mathbf{F}_{2} \mathbf{p o p u l a t i o n s}(\mathbf{\%})$ \\
\hline Days to heading & 59.45 & 6.26 & 34.40 \\
Plant height & 60.39 & 2.29 & 37.32 \\
Flag leaf area & 54.96 & 8.33 & 36.71 \\
Tillers plant $^{-1}$ & 19.68 & 24.18 & 56.14 \\
Grain yield plant $^{-1}$ & 37.41 & 14.96 & 47.63 \\
Harvest index plant $^{-1}$ & 61.97 & 3.32 & 34.72 \\
\hline
\end{tabular}

\section{DISCUSSION}

Overall, all the genotypes (parental cultivars and their $F_{2}$ populations) exhibited significant $(p \leq 0.01)$ differences for earliness, morphological and yield traits which authenticated that genotypes have larger genetic variation and more chances of improvement through intensive selection in the later segregating genotypes. Past combining ability studies also revealed significant variability among the parental cultivars and their $F_{1}$ and $\mathrm{F}_{2}$ populations for various agronomic parameters in wheat (Afridi, 2016; Adhikari et al., 2020; Dhoot et al., 2020). Parent cultivars and $F_{1}$ and $F_{2}$ populations revealed significant differences for earliness and yield 
traits by evaluating through line $\times$ tester mating design in wheat (Aslam et al., 2014; Abro et al., 2016).

In combining ability analysis, lines revealed significant differences for the majority of the traits, while line-by-tester $F_{2}$ populations were significant for all the traits. Past studies on combining ability analysis revealed the ability and contribution of the parental cultivars to unite their positive genes in $F_{1}$ and $F_{2}$ progenies after hybridization (Kempthorne, 1957; Singh and Chaudhary, 1985; Verma et al., 2016). Earlier studies about combining ability revealed similar patterns of significance and inheritance for yield variables in wheat (Tabassum et al., 2017; Farooq et al., 2019; Parveen et al., 2019; Sharma et al., 2019; Ayoob, 2020). However, some of the diallel studies revealed nonsignificant variations among the populations for components of combining ability in bread wheat (Ljubicic et al., 2014).

In present studies, the $\mathrm{F}_{2}$ populations i.e., IBWSN-177 $\times$ Pirsabak-15, IBWSN-52 $\times$ Pakhtunkhwa15, and line SRN-09111 were observed with early flowering and were believed to be the best specific and general combiners, respectively for earliness traits. Present findings also revealed that high $\times$ low and low $\times$ low GCA parent cultivars were involved in the formation of these promising $\mathrm{F}_{2}$ populations. Wheat genotypes with the least days to flowering and maturity could be used as a gene source for developing early maturing wheat genotypes in future breeding programs (Murugan and Kannan, 2017; Rahul, 2017). Earlier findings revealed that for earliness traits, the parental cultivars exhibited negative GCA while some of the wheat genotypes were noted with significant negative SCA which supports the current findings (Afridi, 2016; Saeed and Khalil, 2017; Afridi et al., 2018). Therefore, such genotypes can be utilized in the development of early maturing genotypes with optimum yield.

Results revealed that $\mathrm{F}_{2}$ populations i.e., SRN$09111 \times$ Shahkar-13 and NR-21 $\times$ Pakhtunkhwa-15 showed least plant stature and were found as desirable populations for decreased plant height. High $\times$ low GCA parents played a vital role in these $F_{2}$ populations with the best mean performance. Short stature wheat genotypes are mostly preferred because dwarf wheat genotypes have the minimum chances of lodging. In past studies, lines and testers were found with negative GCA and their line by tester populations also revealed negative SCA for plant height in wheat (Hei et al., 2015; attar et al., 2018). Earlier findings revealed that lines were found as excellent parental genotypes for crossing with various testers for plant height and yield-related traits in wheat (Istipliler et al., 2015).

In case of flag leaf area and tillers number, the $\mathrm{F}_{2}$ populations IBWSN-52 $\times$ Pakhtunkhwa-15, IBWSN$177 \times$ Shahkar-13, IBWSN-177 $\times$ Pakhtunkhwa-15, PR$107 \times$ Shahkar-13, and tester Shahkar-13 were found as prominent specific and general combiners and performed better for said traits. Wheat genotypes with greater flag leaf area have more ability to fix the inorganic carbon by photosynthetic activity. Flag leaf area potentially contributes to grain filling by translocation of carbohydrates in grains during the post-anthesis period in wheat (Sattar et al., 2018). In wheat crop, flag leaf contributes to spike development, grain filling, and grain yield (Aslam et al., 2014; Afridi et al., 2017a). Wheat genotypes with greater tillering capacity are more preferable. Tiller number can be used as a selection criterion in wheat breeding because it significantly contributes to grain and biological yields (Murugan and Kannan, 2017; Rajput and Kandalkar, 2018). Past studies revealed that lines and testers were confirmed with significant positive GCA and were identified as superlative GCA parents for flag leaf and tiller number in wheat (Aslam et al., 2014; Afridi et al., 2017b). In the line-by-tester analysis, most of the parental lines, and testers, and their $F_{1}$ and $F_{2}$ populations were recorded with positive GCA for flag leaf and tiller number in wheat (Abro et al., 2016; Ahmed et al., 2017).

For grain yield, the $\mathrm{F}_{2}$ populations i.e., IBWSN$131 \times$ Pakhtunkhwa-15, IBWSN-131 $\times$ Shahkar-13, and PR107 $\times$ Shahkar-13, while for harvest index the $F_{2}$ population IBWSN-131 $\times$ Pakhtunkhwa-15 and line PR107 were identified as best specific and general combiners, respectively which performed better for grain yield and harvest index. In earlier studies, grain yield was primarily affected by tillers, spike traits, and seed index in wheat (Istipliler et al., 2015; Ingle et al., 2018). In previous studies, sizeable variations were exhibited by $F_{1}$ and $F_{2}$ populations and showed increased grain yield than parental genotypes in wheat (Abro et al., 2016; Afridi et al., 2019). Grain yield is directly related to harvest index, and hence, genotypes with higher harvest index ultimately had the increased grain yield in wheat (Jain and Sastry, 2012; Rajput and Kandalkar, 2018). In bread wheat, the lines and testers showed positive GCA and the majority of the $F_{1}$ and $F_{2}$ populations exhibited positive SCA for grain yield and its components (Fellahi et al., 2013; Aslam et al., 2014). Previous studies revealed that parent female and male cultivars, and some of their $F_{1}$ populations had significant positive GCA for harvest index in combining ability studies in wheat (Abro et al., 2016; Saeed and Khalil, 2017).

Based on variances due to GCA and SCA and their ratios, and degree of dominance, it was authenticated that inheritance in all the traits was managed by dominant gene action. Therefore, the assortment of the superior populations in terms of earliness, morphological and yield variables should be delayed to later segregating generations. Past studies revealed that variations due to GCA and SCA and their ratio showed dominant gene action for the majority of the traits in wheat (Hei et al., 2015; Murugan and Kannan, 2017; Saeed and Khalil, 2017). The ratios of genetic 
differences owing to GCA to SCA indicated that the legacy of the majority of variables was managed by dominant gene action in wheat (Ingle et al., 2018; Younas et al., 2020). However, some studies revealed that earliness and production traits were controlled by additive gene action in wheat (Ljubicic et al., 2014; Mandal and Madhuri, 2016; Adhikari et al., 2020). Some past investigations revealed that inheritance of various traits in wheat was influenced by both additive and dominant gene actions (Rashid et al., 2012; Aslam et al., 2014; Abro et al., 2016).

In relative involvement of genotypes to the total variance, the lines and line-by-tester $F_{2}$ populations had maximum share in total variance and controlled the majority of variation in the studied traits. In the past studies, the contribution by line-by-tester populations to total variances was much larger than lines and testers individually in wheat (Istipliler et al., 2015). Past studies about line-by-tester combining ability revealed that relative inputs of line $\times$ tester populations to total variance was leading and managed the variances for earliness and yield traits in wheat (Sattar et al., 2018).

Conclusion: Parental lines IBWSN-131 and Shahkar-13, and $F_{2}$ populations IBWSN-131 $\times$ Pakhtunkhwa-15, IBWSN-131 × Shahkar-13, and PR107 $\times$ Shahkar-13 were identified as promising general and specific combiners, respectively by showing best performance for earliness and yield traits. High $\times$ high and low $\times$ high GCA parents were involved in these $F_{2}$ populations for the majority of the traits. Therefore, these populations could be utilized in the future breeding program to build on the wheat cultivars with early maturity and greater yield potential. Ratios of the variances of GCA to SCA and degree of dominance confirmed that all the studied traits were managed by dominant gene action. Nonadditive gene action recommended that the assortment of promising populations should be delayed to later segregating generations for further improvement in wheat.

\section{REFERENCES}

Abro, S.A., A.W. Baloch, M. Baloch, G.A. Baloch, T.A. Baloch, A.A. Soomro, Q. Jogi and M. Ali (2016). Line $\times$ tester analysis for estimating combining ability in $\mathrm{F}_{1}$ hybrids of bread wheat. Pure Appl. Biol. Sci. 5(3): 647-652.

Adhikari, A., A.M.H. Ibrahim, J.C. Rudd, P.S. Baenziger and J.B. Sarazin (2020). Estimation of heterosis and combining abilities of U.S. winter wheat germplasm for hybrid development in Texas. Crop Sci. 60(2): 788-803.

Afridi, K. (2016). Inheritance of yellow rust resistance and glutenin content in wheat. Ph.D Dissertation. Department of Plant Breeding and
Genetics, The University of Agriculture, Peshawar, Pakistan

Afridi, K., N.U. Khan, F. Mohammad, S.J.A. Shah, S. Gul, I.A. Khalil, M. Sajjad, S. Ali, I. Ali and S.M. Khan (2017a). Inheritance pattern of earliness and yield traits in half diallel crosses of spring wheat. Can. J. Plant Sci. 97: 865-880

Afridi, K., N.U. Khan, F. Mohammad, S.U. Khan, S.H. Shah and S.J.A. Shah (2017b). Genetic expression of yellow rust resistance, yield and yield related traits in wheat using Griffing's combining ability analysis. Pakistan J. Bot. 49: 2005-2013

Afridi, K., N.U. Khan, S. Gul, Z. Bibi, S. Ali, N. Ali, S.A. Khan, S.M. Khan, I.A. Khalil and A. Khan (2019). Genetic characterization of stripe rust and yield traits in bread wheat. Int. J. Agric. Biol. 21(3): 621-629.

Afridi, K., N.U. Khan, Z. Bibi, S. Gul, R. Gul, S. Ali, N. Ali, I.A. Khalil, F. Uddin and G. Ahmad (2018). Assessment of genetic effects for earliness and yield traits in $F_{1}$ and $F_{2}$ half diallel populations of wheat. Int. J. Agric. Biol. 20: 2785-2796

Ahmad, E., M. Akhtar, S. Bhadoni and J.P. Jashwal (2017). Combining ability studies for seed yield related attributes and quality parameters in bread wheat ( $T$. aestivum L.). J. Genet. Genomics Plant Breed. 1(1): 21-27.

Ahmed, H.G.M.D., M. Rizwan, H.A. Anwaar. A. Qadeer, Z. Zafar and H. Jamil (2017). Combining ability analysis for morphological traits in wheat. Int. J. Biosci. 11(4): 41-47.

Anonymous (2018-2019). Pakistan Economic Survey 2018-2019. Pakistan Bureau of Statistics (PBS), Ministry of Finance, Revenue and Economic Affairs, Govt. of Pakistan, Islamabad, Pakistan.

Ashraf, S., S. Malook, I. Naseem, N. Ghori, S. Ashraf, S.A. Qurashi, S. Khalid, I. Khaliq and W. Amin (2015). Combining ability analysis is a breeding approach to develop drought tolerance of wheat genotype. Am. Eur. J. Agric. Environ. Sci. 15(3): 415-423.

Aslam, R., M. Munawar and A. Salam (2014). Genetic architecture of yield components accessed through line $\times$ tester analysis in wheat $(T$. aestivum L.). Univers. J. Plant. Sci. 2(5): 93-96.

Ayoob, M.H. (2020). Combining ability analysis, estimation of heterosis and some genetic parameters using half diallel cross in bread wheat (T. aestivum L.). J. Edu. Sci. 29(1): 93106.

Bhanu, A.N., B. Arun and V.K. Mishra (2018). Genetic variability, heritability and correlation study of physiological and yield traits in relation to heat tolerance in wheat (T. aestivum L.). Biomed. J. Sci. Tech. Res. 2(1): 1-5. 
Dhoot, M., H. Sharma, R.B. Dubey, V.K. Badaya and R. Dhoot (2020). Combining ability analysis for yield and some of its associated characters in late sown condition in bread wheat (T. aestivum L. em. Thell). J. Pharmacognosy Phytochem. 9(2): 283-286.

Farooq, M.U., I. Ishaaq, R. Maqbool, I. Aslam, S.M.T.A. Naqvi and S. Mustafa (2019). Heritability, genetic gain and detection of gene action in hexaploid wheat for yield and its related attributes. AIMS Agric. Food 4(1): 56-72.

Fasahat, P., A. Rajabi, J.M. Rad and J. Derera (2016). Principles and utilization of combining ability in plant breeding. Biom. Biostat. Int. J. 4(1):1-22.

Fellahi, Z.A., A. Hannachi, H. Bourzerzour and A. Boutekrabt (2013). Line $\times$ tester mating design analysis for grain yield and yield related traits in bread wheat (T. aestivum L.). Int. J. Agron. 2: 19.

Griffing B. (1956). Concept of general and specific combining ability in relation to diallel crossing systems. Aust. J. Biol. Sci. 9: 463-493.

Hama-Amin, T.N. and S.I. Towfiq (2019). Estimation of some genetic parameters using line $\times$ tester analysis of common wheat ( $T$. aestivum L.). Appl. Ecol. Environ. Res. 17(4): 9735-9752.

Hei, N., S. Hussein and M. Laing (2015). Heterosis and combining ability analysis of slow rusting stem rust resistance and yield and related traits in bread wheat. Euphytica 207: 501-514.

Ingle, N.P., P.B. Wadikar and P.M. Salunke (2018). Combining ability and gene action studies for grain yield and yield contributing traits in wheat (T. aestivum L.). Int. J. Curr. Microbiol. Appl. Sci. 7(8): 2684-2691.

Ismail, S.K.A. (2015). Heterosis and combining ability analysis for yield and its components in bread wheat (T. aestivum L.). Int. J. Curr. Microbiol. Appl. Sci. 4(8):1-9.

Istipliler, D., E. Ilker, F.A. Tonk, G. Civi and M. Tosun (2015). Line $\times$ tester analysis and estimating combining abilities for yield and some yield components in bread wheat. Turk. J. Field Crops 20(1): 72-77.

Jain, S.K. and E.V.D. Sastry (2012). Heterosis and combining ability for grain yield and contributing trait in bread wheat. J. Agric. Appl. Sci. 1(1): 17-22.

Kandil, A.A., A.E. Sharief and H.S.M. Gomaa (2016). Estimation of general and specific combining ability in bread wheat ( $T$. aestivum L.). Int. J. Agric. Res. 8(2): 37-44.

Kempthorne, O. (1957). Introduction to Genetic Statistics. John Valley and Sons. London, Chapman and Hall. Ltd.
Khiabani, B.N., S. Aharizad and S.A. Mohammadi (2015). Genetic analysis of grain yield and plant height in full diallel crosses of bread wheat. Biol. Forum 7(1): 1164-1172.

Khokhar, A.A., F.G. Nizamani, R.A. Rind, M.M. Nizamani, M.U. Khokhar, A, Shah, A.L. Nizamani and M.R. Rind (2019). Combining ability estimates in $6 \times 6$ half diallel crosses of bread wheat (T. aestivum L.). Pure Appl. Biol. 8(3): 1980-1990.

Kumar, D., A. Kumar, A. Kumar, S. Kaur and A.K. Yadav (2018). Combining ability for yield attributing traits in wheat ( $T$. aestivum L.). J. Pharm. Phytochem. 2730-2735.

Ljubicic, N., S. Petrovic, M. Dimitrijevic and N. Hristov (2014). Inheritance of the grain number per spike in diallel cross of 5 x 5 bread wheat cultivars. Ratar. Povrt. 51(3): 166-169.

Mandal, A.B. and G. Madhuri (2016). Combining ability analysis for morphological and yield traits in wheat (T. aestivum L.). J. Plant Sci. Res. 3(2): 157-162.

Minhas, N.M., S.U. Ajmal, Z.I. Ahmad and M. Munir (2014). Genetic analysis for grain quality traits in Pakistani wheat varieties. Pakistan J. Bot. 46(4): 1409-1413.

Murugan, A. and R. Kannan (2017). Heterosis and combining ability analysis for yield traits of Indian hexaploid wheat ( $T$. aestivum L.). Int. J. Recent Sci. Res. 8(7): 18242-18246.

Parveen, N., M. Iqbal, M. Tahir, S. Aleem, R. Aslam, E. Amin, K.L. Cheema and A.S. Khan (2019). Assessment of heritable variation and best combining genotypes for grain yield and its attributes in bread wheat. Am. J. Agric. Res. 4(31): 1-9.

Quarrie, S.A. and H.G. Jones (1979). Genotype variation in leaf water potential, stomatal conductance and abscisic acid concentration in spring wheat subjected to artificial drought stress. Ann. Bot. 44: 323- 332.

Rahul, S.R. (2017). Combining ability and heterosis for morpho-physiological characters on bread wheat (T. aestivum L.). J. Agric. Res. Technol. 13(1): $1-9$.

Rajput, R.S. (2019). Path analysis and genetic parameters for grain yield in bread wheat ( $T$. aestivum L.). Annu. Res. Rev. in Biol. 31(3): 1-8.

Rajput, R.S. and V.S. Kandalkar (2018). Combining ability and heterosis for grain yield and its attributing traits in bread wheat (T. aestivum L.). J. Pharm. Phytochem. 7(2): 113-119.

Rashid, M.A.R., A.S. Khan and R. Iftikhar (2012). Genetic study for yield and yield related parameter in bread wheat. Am. Eur. J. Sci. 2(10): 790-796. 
Sabit, Z., D.B. Yadav and D.P.K. Rai (2017). Genetic variability, correlation and path analysis for yield and its components in $\mathrm{F}_{5}$ generation of bread wheat (T. aestivum L.). J. Pharm. Phytochem. 6(4): 680-687.

Saeed, M. and I.H. Khalil (2017). Combining ability and narrow-sense heritability in wheat (T. aestivum L.) under rainfed environment. Sarhad J. Agric. 33(1): 22-29.

Sattar, S., B. Nawaz. A. Tahir, A. Ahmed, M. Naeem, M.Z. Ghouri and M. Jamshid (2018). Gene action and combining ability analysis of quantitative traits associated with grain yield in wheat under drought stress and normal irrigation conditions. Global J. Bio-Sci. Biotechnol. 7(4): 642-650.

Sharma, V., N.S. Dodiya1, R.B. Dubey and R. Khan (2019). Combining ability analysis in bread wheat (T. aestivum (L.) em. Thell) under different environmental conditions. Bangladesh J. Bot. 48(1): 85-93.

Singh, R.K. and B.D. Chaudhary (1985). Biometrical method in quantitative genetics analysis. Kalyani Publishers, Ludhiana, New Dehli, India.

Sprague, G.F. and L.A. Tatum (1942). General vs. specific combining ability in single crosses of corn. J. Am. Soc. Agron. 34: 923-932.
Steel, R.G.D., J.H. Torrie and D.A. Dickey (1997). Principles and Procedures of Statistics: A Biometrical Approach, $3^{\text {rd }}$ ed. McGraw Hill Book Co., Inc., New York.

Tabassum, A. Kumar and B. Prasad (2017). Study of combining ability and nature of gene action for yield and its contributing traits in bread wheat (T. aestivum L. em Thell). Int. J. Curr. Microbiol. Appl. Sci. 6(10): 3562-3573.

Tiwari, R., S. Markea and D.R. Meghwal (2017). Combining ability estimates for spike characters in $F_{1}$ hybrids developed through diallel crosses among macaroni wheat (T. durum.) genotypes. J. Pharm. Phytochem. 6(2): 237-241.

Verma, S., R. Maura and S. Maura (2016). Prediction of gene action and combining ability for yield and quality traits in $F_{1}$ and $F_{2}$ generations of wheat (T. aestivum L.). Int. J. Soc. Plant Res. 3(2): 449-459.

Worldometer (2020). Elaboration of data by United Nations, Department of Economic and Social Affairs, Population Division. World Population Prospects: The 2020 Revision (www.worldometers.info).

Younas, A., H.A. Sadaqat, M. Kashif, N. Ahmed and M. Farooq (2020). Combining ability and heterosis for grain iron biofortification in bread wheat. J. Sci. Food Agric. 100(4): 1570-1576. 